\title{
PENGARUH DISIPLIN BELAJAR, LINGKUNGAN SOSIAL, DAN VARIASI GAYA MENGAJAR GURU TERHADAP HASIL BELAJAR MATEMATIKA SISWA KELAS XI IPA SMAN 3 DAN SMAN 5 SAMARINDA
}

\author{
Ani Lestari \\ Sugeng ${ }^{1)}$ \\ ${ }^{1)}$ Dosen Pendidikan Matematika FKIP Universitas Mulawarman \\ Email: ${ }^{1)}$ sugeng@fkip.unmul.ac.id
}

\begin{abstract}
ABSTRAK
Penelitian ex post facto ini bertujuan untuk mengetahui pengaruh disiplin belajar, lingkungan sosial dan variasi gaya mengajar guru terhadap hasil belajar matematika siswa pada materi Matriks di kelas XI IPA SMAN 3 dan SMAN 5 Samarinda Tahun Ajaran 2017/2018. Pengambilan sampel menggunakan teknik proportional cluster random sampling dan diperoleh sampel berukuran 201 siswa. Pengambilan data dilakukan dengan menggunakan angket disiplin belajar, lingkungan sosial, variasi gaya mengajar guru dan tes hasil belajar matematika, yang sebelumnya keempat instrumen itu dilakukan ujicoba. Analisis data dengan teknik regresi linear ganda diperoleh persamaan regresi dugaan $\hat{Y}=-55,691+0,418 X_{1}+0,464 X_{2}+0,321 X_{3}$, dengan $F=11.512$, pada $\alpha=0,05$. Hasil penelitian menunjukkan bahwa disiplin belajar, lingkungan sosial dan variasi gaya mengajar guru secara bersama-sama memberikan pengaruh yang signifikan terhadap hasil belajar matematika siswa dengan sumbangan sebesar 13,6\%. Secara parsial disiplin belajar, lingkungan sosial dan variasi gaya mengajar guru memberikan pengaruh terhadap hasil belajar matematika siswa SMA, secara berurutan sebesar $r^{2}=5,1 \% ; r^{2}=7,0 \%$; dan $r^{2}=5,3 \%$.
\end{abstract}

Kata kunci: Disiplin Belajar, Lingkungan Sosial, Variasi Gaya Mengajar Guru, Hasil Belajar.

\begin{abstract}
This ex post facto research aims to determine the effect of learning discipline, social environment and variations in teacher teaching styles on student mathematics learning outcomes on Matrix material in class XI IPA SMAN 3 and SMAN 5 Samarinda Academic Year 2017/2018. Sampling using proportional cluster random sampling technique and obtained a sample size of 201 students. Data collection is done by using a discipline of learning questionnaire, social environment, variations in teacher teaching styles and mathematics learning achievement tests, and previously the four instruments were tested. Data analysis with multiple linear regression techniques obtained by the estimated regression equation: $\hat{Y}=-55,691+0,418 X_{1}+0,464 X_{2}+0,321 X_{3}$, with $F=11.512$, at $\alpha=0,05$. The results showed that the discipline of learning, social environment and variations in teaching styles of teachers together gave a significant influence on student mathematics learning outcomes with a contribution of $13.6 \%$. Partially the discipline of
\end{abstract}


learning, social environment and variations in the teaching style of the teacher gives an influence on the mathematics learning outcomes of high school students, in sequence of $r^{2}=5.1 \% ; r^{2}=7.0 \%$; and $r 2=5.3 \%$.

Keywords: Learning Dicipline, Social Environment, Variety of Teacher Teaching Styles, Learning Outcomes.

\section{PENDAHULUAN}

Pendidikan memegang peranan penting dalam menentukan kualitas sumber daya manusia, karena pendidikan merupakan sarana untuk meningkatkan dan mengembangkan kualitas sumber daya manusia yang dapat menjamin kelangsungan hidup suatu bangsa. Tujuan dan fungsi pendidikan secara umum adalah memberikan dasar yang dibutuhkan oleh siswa dalam kehidupan sehari-hari. Selain itu, melalui pendidikan diharapkan siswa mampu menjadi manusia yang berprestasi tinggi agar dapat bersaing di era globalisasi. Siswa yang berkualitas adalah siswa yang memiliki prestasi baik. Namun dalam upaya meraih prestasi belajar yang memuaskan dibutuhkan proses belajar.

Menurut Slameto (2013) belajar ialah suatu proses usaha yang dilakukan seseorang untuk memperoleh suatu perubahan tingkah laku yang baru secara keseluruhan, sebagai hasil pengalamannya sendiri dalam interaksi dengan lingkungannya. Perubahan dalam diri seseorang dapat menyangkut pengetahuan, kecakapan dan keterampilan.

Matematika sebagai salah satu mata pelajaran yang diajarkan di sekolah memegang peranan penting dalam membentuk siswa yang berkualitas. Pelajaran matematika yang diajarkan berguna untuk menumbuh kembangkan kemampuan dan pembentukkan pribadi siswa seiring dengan perkembangan ilmu pengetahuan dan teknologi. Menyadari pentingnya peranan matematika, maka peningkatan hasil belajar matematika di sekolah-sekolah perlu mendapat perhatian yang sungguh-sungguh.

Dalam usaha peningkatan prestasi belajar matematika siswa, secara umum ada dua faktor yang mempengaruhi yaitu faktor dari dalam diri siswa (faktor intern) dan faktor dari luar diri siswa (faktor ekstern). Faktor dari dalam diri siswa antara lain: minat, perhatian, motivasi, sikap, gaya belajar, disiplin, kebiasaan belajar. Faktor eksternal dapat berupa keadaan keluarga, keadaan awal, teman sebaya, tempat tinggal, guru yang mengajar, cara mengajar, dan lingkungan sosial.

Disiplin merupakan nilai-nilai karakter yang dikembangkan di sekolah. Menurut Walgito, (2008) disiplin adalah ketaatan dan kepatuhan dalam melaksanakan aktivitas belajar sesuai aturannya untuk mencapai tujuan yang diharapkannya, keterikatan antara disiplin belajar dengan hasil belajar sangat erat sehingga semakin berdisiplin dalam belajar semakin baik hasil yang dicapai, begitu pula sebaliknya. Berdasarkan pengamatan di SMAN 3 Samarinda, disiplin belajar siswa masih sangat kurang, dimana dapat dilihat dari tindakan siswa yang terlambat masuk kelas, tidak mengerjakan tugas, tidak memperhatikan guru pada saat pelajaran matematika, membolos mata pelajaran matematika.

2 Pengaruh disiplin belajar, lingkungan sosial, dan variasi gaya mengajar guru Ani Lestari - Sugeng 
Selain disiplin belajar, lingkungan sosial siswa di sekolah juga ikut berperan dalam mempengaruhi hasil belajar siswa. Menurut Saroni (dalam Asmani, 2013) lingkungan sosial di sekolah berhubungan dengan pola interaksi antarpersonil yang ada di lingkungan sekolah secara umum.

Berdasarkan kenyataan yang terlihat di SMA Negeri 3 Samarinda yaitu lingkungan sosial yang mewujud dalam suasana tidak akrab, karena sebagian siswa lebih senang berkumpul dan bermain sehingga siswa yang sedang belajar merasa terganggu. Siswa yang mempunyai sifatsifat atau tingkah laku yang kurang menyenangkan teman lain, mempunyai rasa rendah diri, akan diasingkan dari kelompok. Selain itu guru kurang berinteraksi dengan siswa secara akrab, sehingga siswa segan berpartisipasi secara aktif dalam belajar

Faktor kebosanan yang disebabkan oleh adanya penyajian kegiatan belajar yang klasikal mengakibatkan perhatian, motivasi dan minat siswa terhadap pelaja- adalah perubahan dalam proses kegiatan yang bertujuan untuk meningkatkan motivasi belajar peserta didik, serta mengurangi kejenuhan dan kebosanan.

Berdasarkan observasi yang telah dilakukan, terlihat guru hanya berdiri di depan papan tulis saja dalam menjelaskan materi, sehingga tidak memperhatikan siswa yang sedang asyik bermain sendiri, selain itu perhatian guru hanya terpusat pada siswa yang aktif, sehingga siswa yang pasif sering tidak memperhatikan penjelasan guru.

\section{METODE PENELITIAN}

Penelitian ini menggunakan jenis rancangan penelitian ex post facto. Menurut Ary, Jacobs, dan Razaviech (dalam Sugeng, 2014), penelitian ex post facto merupakan penelitian serupa dengan penelitian eksperimental, hanya penelitian tidak dapat secara langsung memanipulasi variabel bebas. Model rancangan penelitian pada gambar 1 .

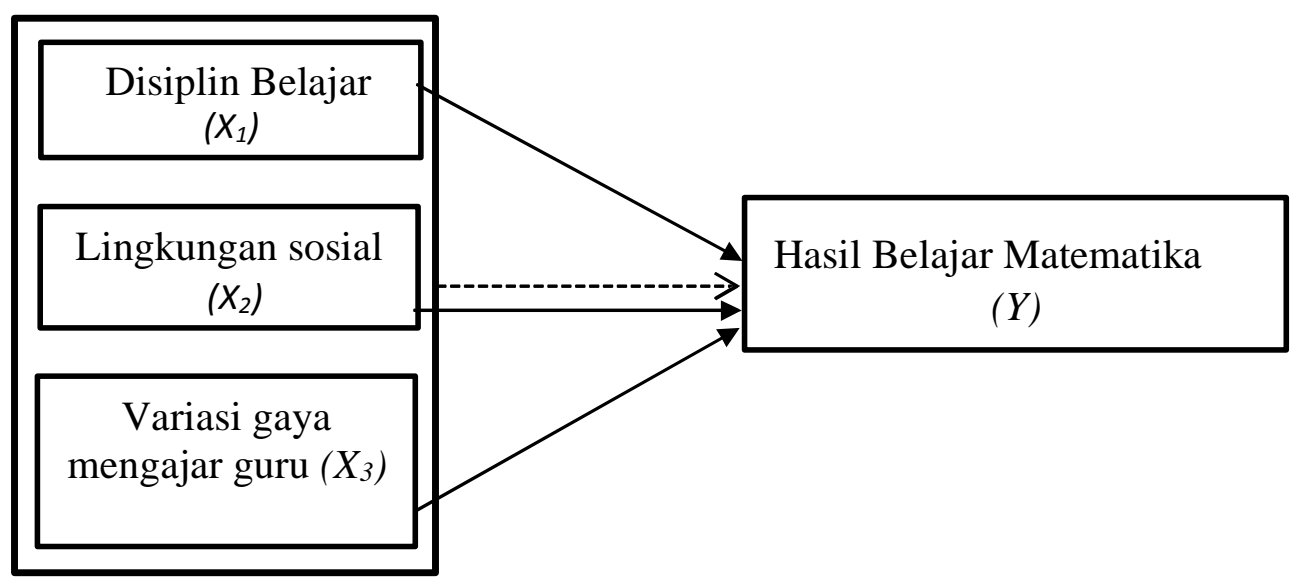

Gambar 1. Rancangan penelitian

ran, guru, dan sekolah menurun. Untuk itu perlu adanya keanekaragaman dalam penyajian kegiatan belajar. Menurut Mulyasa (2008) variasi dalam pembelajaran
Penelitian ini dilaksanakan pada bulan November 2017 di SMAN 3 dan SMAN 5 Samarinda, Kecamatan Samarinda Ulu tahun pembelajaran 2017/2018. Popu- 
lasi dalam penelitian ini adalah seluruh siswa kelas XI IPA SMAN 3 dan SMAN 5 Samarinda tahun ajaran 2017/2018 yang berjumlah 421 siswa.

Teknik pengumpulan data yang digunakan berupa angket dan tes. Angket digunakan untuk memperoleh data disiplin belajar, lingkungan sosial, dan variasi gaya mengajar guru. Tes digunakan untuk memperoleh data hasil belajar matematika siswa.

Indikator disiplin belajar terdiri dari ketaatan terhadap tata tertib sekolah, ketaatan terhadap kegiatan belajar disekolah, ketaatan dalam mengerjakan tugastugas pelajaran, dan ketaatan terhadap kegiatan belajar di rumah yang berguna untuk mengukur tingkat disiplin belajar siswa kelas XI IPA SMAN 3 dan SMAN 5 Samarinda.

Indikator lingkungan sosial terdiri dari interaksi antar siswa, interaksi antara siswa dengan guru dan interaksi antara siswa dan karyawan di sekolah yang berguna untuk mengukur lingkungan sosial siswa kelas XI IPA SMAN 3 dan SMAN 5 Samarinda. didik, gerakan badan mimik, serta pergantian posisi guru di dalam kelas yang berguna untuk mengukur variasi gaya mengajar guru kelas XI IPA SMAN 3 dan SMAN 5 Samarinda.

Teknik analisis data yang digunakan adalah statistik deskriptif dan inferensial. Sedangkan untuk menguji hipotesis digunakan regresi linier ganda. Pada pengujian hopotesis akan dilihat, apakah ada pengaruh ketiga variabel bebas scara bersama-sama terhadap variabel terikat. Pengujian selanjutnya akan dilihat, apakah ada pengaruh masing-masing variabel bebas terhadap variabel terikat secara parsial.

\section{HASIL PENELITIAN DAN PEMBA-} HASAN

\section{A. Hasil Penelitian \\ 1. Statistik Deskriptif}

Berdasarkan tabel 1, dapat diketahui bahwa siswa yang memperoleh kategori sangat rendah sebanyak 17 siswa dengan persentase sebesar 7,6\%, yang memperoleh kategori rendah sebanyak 51 siswa dengan

Tabel 1. Distribusi skor variabel disiplin belajar

\begin{tabular}{|c|c|c|c|}
\hline \multicolumn{2}{|c|}{ Skor Disiplin Belajar } & Frekuensi & Persentase \\
$(\mathbf{F})$ & Kategori & 17 & 7,6 \\
\hline$X \leq 90$ & Sangat Rendah & 17 & 22,9 \\
\hline $90<X \leq 100$ & Rendah & 51 & 36,8 \\
\hline $100<X \leq 109$ & Sedang & 82 & 27,8 \\
\hline $109<X \leq 119$ & Tinggi & 62 & 4,9 \\
\hline$X>119$ & Sangat Tinggi & 11 & 100 \\
\hline \multicolumn{2}{|c|}{ Jumlah } & 223 & \\
\hline
\end{tabular}

Indikator variasi gaya mengajar guru terdiri dari penggunaan variasi suara, pemusatan perhatian siswa, pemberian waktu, mengadakan kontak padang dengan peserta persentase sebesar $22,9 \%$, yang memperoleh kategori sedang sebanyak 82 siswa dengan persentase sebesar $36,8 \%$, yang memperoleh kategori tinggi sebanyak 62 
siswa dengan persentase sebesar $27,8 \%$, dan kategori tinggi sebanyak 11 siswa dengan persentase sebesar $4,9 \%$. Secara keseluruhan dalam penelitian ini terlihat bahwa lebih dari $30 \%$ siswa memiliki disiplin belajar dengan kategori sedang.

Berdasarkan tabel 2, terlihat bahwa siswa yang memperoleh kategori sangat ren
Berdasarkan tabel 3, terlihat sebanyak 16 siswa dengan persentase sebesar 7,2\% menyatakan variasi gaya mengajar guru kategori sangat rendah, yang menyatakan variasi gaya mengajar guru termasuk kategori rendah sebanyak 57 siswa dengan persentase sebesar $25,6 \%$, yang menyatakan variasi gaya mengajar guru termasuk

Tabel 2. Distribusi skor variabel lingkungan sosial

\begin{tabular}{|c|c|c|c|}
\hline \multicolumn{2}{|c|}{ Skor Lingkungan Sosial } & \multirow{2}{*}{$\begin{array}{l}\text { Frekuensi } \\
\text { (F) }\end{array}$} & \multirow{2}{*}{$\begin{array}{c}\text { Persentase } \\
(\%)\end{array}$} \\
\hline Interval & Kategori & & \\
\hline$X \leq 90$ & Sangat Rendah & 17 & 7,6 \\
\hline $90<X \leq 100$ & Rendah & 49 & 22,0 \\
\hline $100<X \leq 109$ & Sedang & 84 & 37,7 \\
\hline $109<X \leq 119$ & Tinggi & 65 & 29,1 \\
\hline$X>119$ & Sangat Tinggi & 8 & 3,6 \\
\hline \multicolumn{2}{|c|}{ Jumlah } & 223 & 100 \\
\hline
\end{tabular}

Tabel 3. Distribusi skor variabel variasi gaya mengajar guru

\begin{tabular}{|c|c|c|c|}
\hline \multicolumn{2}{|c|}{ Skor Var. Gaya Meng. Guru } & Frekuensi & Persentase \\
Interval & Kategori & $(\mathbf{\%})$ & 7,2 \\
\hline$X \leq 77$ & Sangat Rendah & 16 & 77 \\
\hline $77<X \leq 85$ & Rendah & 57,6 \\
\hline $85<X \leq 94$ & Sedang & 78 & 35,0 \\
\hline $94<X \leq 103$ & Tinggi & 57 & 29,1 \\
\hline$X>103$ & Sangat Tinggi & 15 & 6,7 \\
\hline \multicolumn{2}{|c|}{ Jumlah } & 223 & 100 \\
\hline
\end{tabular}

dah sebanyak 17 siswa dengan persentase sebesar 7,6\%, yang memperoleh kategori rendah sebanyak 49 siswa dengan persentase sebesar $22,0 \%$, yang memperoleh kategori sedang sebanyak 84 siswa dengan persentase sebesar $37,7 \%$, yang memperoleh kategori tinggi sebanyak 65 siswa dengan persentase sebesar $29,1 \%$, dan kategori tinggi sebanyak 8 siswa dengan persentase sebesar 3,6\%. Secara keseluruhan dalam penelitian ini terlihat bahwa lebih dari $30 \%$ siswa memiliki lingkungan sosial dengan kategori sedang. kategori sedang sebanyak 78 siswa dengan persentase sebesar $35,0 \%$, yang menyatakan variasi gaya mengajar guru termasuk kategori tinggi sebanyak 57 siswa dengan persentase $25,6 \%$, dan menyatakan variasi gaya mengajar guru termasuk kategori sangat tinggi sebanyak 15 siswa dengan persentase sebesar 6,7\%. Secara keseluruhan dalam penelitian ini terlihat bahwa lebih dari $30 \%$ siswa menyatakan variasi gaya mengajar guru termasuk kategori sedang. 
Berdasarkan tabel 4, dapat diketahui bahwa siswa yang memperoleh nilai dengan kategori sangat rendah sebanyak 101 siswa dengan persentase $45,3 \%$, yang memperoleh kategori rendah sebanyak 33 siswa dengan persentase sebesar $14,8 \%$, yang memperoleh kategori sedang sebanyak 33 siswa dengan persentase sebesar $14,8 \%$, yang memperoleh kategori tinggi sebanyak 42 siswa dengan persentase sebesar $18,8 \%$, dan kategori sangat tinggi sebanyak 14 siswa dengan persentase sebesar 6,3\%. Secara keseluruhan dalam penelitian ini terlihat bahwa lebih dari $40 \%$, hasil belajar matematika siswa dibawah kategori rendah. data untuk variabel disiplin belajar, lingkungan sosial, variasi gaya mengajar guru, dan hasil belajar matematika berasal dari populasi yang berdistribusi normal.

b. Uji hetereskedastisitas

Berdasarkan scatter plot dependent variable menghasilkan pola diagram pencar yang tidak membentuk suatu pola tertentu sehingga data yang digunakan pada penelitian ini bersifat homogen.

\section{c. Uji linieritas}

Berdasarkan hasil perhitungan deviation from linearity, nilai sig. untuk disiplin belajar sebesar 0,124, nilai sig. untuk lingkungan sosial sebesar 0,795 , dan nilai

Tabel 4. Distribusi skor variabel hasil belajar matematika siswa

\begin{tabular}{|c|c|c|c|}
\hline \multicolumn{2}{|c|}{ Skor Hasil Belajar } & \multirow{2}{*}{$\begin{array}{l}\text { Frekuensi } \\
\text { (F) }\end{array}$} & \multirow{2}{*}{$\begin{array}{c}\text { Persentase } \\
(\%)\end{array}$} \\
\hline Interval & Kategori & & \\
\hline$X \leq 90$ & Sangat Rendah & 101 & 45,3 \\
\hline $90<X \leq 100$ & Rendah & 33 & 14,8 \\
\hline $100<X \leq 109$ & Sedang & 33 & 14,8 \\
\hline $109<X \leq 119$ & Tinggi & 42 & 18,8 \\
\hline$X>119$ & Sangat Tinggi & 14 & 6,3 \\
\hline \multicolumn{2}{|c|}{ Jumlah } & 223 & 100 \\
\hline
\end{tabular}

\section{Statistik Inferensial}

a. Uji normalitas

Dari tabel 5, diketahui bahwa nilai signifikansi statistik pada semua variabel lebih dari nilai signifikansi pengujian $(0,05)$. Sehingga dapat disimpulkan bahwa sig. untuk variasi gaya mengajar guru sebesar 0,303. Karena nilai sig. untuk semua variabel lebih dari 0,05 maka dapat disimpulkan bahwa model regresi berbentuk linier.

Tabel 5. Distribusi hasil uji normalitas

\begin{tabular}{|c|c|c|}
\hline Variabel & Sig. & Hasil. \\
\hline Disiplin Belajar & 0,670 & Normal \\
Lingkungan Sosial & 0,710 & Normal \\
Variasi Gaya Mengajar Guru & 0,467 & Normal \\
Hasil Belajar Matematika & 0,100 & Normal \\
\hline
\end{tabular}




\section{d. Uji multikolinearitas}

Berdasarkan tabel 6, dapat diketahui bahwa masing-masing variabel mempunyai nilai tolerance lebih dari 0,1 dan nilai VIF kurang dari 10 maka tidak terjadi multikolinearitas antara ketiga variabel. sing merupakan koefisien untuk variabel $X_{1}, X_{2}, X_{3}$ sehingga model regresi tersebut dapat disusun menjadi

$$
\begin{aligned}
& \hat{Y}=-55,691+0,418 X_{1}+0,464 X_{2}+ \\
& 0,321 X_{3}
\end{aligned}
$$

Tabel 6. Hasil perhitungan multikolinearitas

\begin{tabular}{|l|c|c|}
\hline \multicolumn{1}{|c|}{ Variabel } & Tolerance & VIF \\
\hline Disiplin Belajar & 0,973 & 1,028 \\
\hline Lingkungan Sosial & 0,961 & 1,041 \\
\hline Variasi Gaya Mengajar Guru & 0,914 & 1,013 \\
\hline
\end{tabular}

e. Uji hipotesis penelitian

Berdasarkan tabel 7, diperoleh nilai sig. sebesar 0,000 sehingga dapat disimpul-

\section{B. Pembahasan}

Hasil penelitian menunjukkan bahwa hasil belajar matematika siswa pada materi

Tabel 7. Tabel anova

\begin{tabular}{|l|c|c|c|c|c|}
\hline \multicolumn{1}{|c|}{ Model } & Sum of Squares & Df & Mean Square & F & Sig \\
\hline Regression & 15436,557 & 3 & 5145,519 & 11,512 & $.000^{\mathrm{b}}$ \\
\hline Residual & 97882,126 & 219 & 446,951 & & \\
\hline Total & 113318,753 & 222 & & & \\
\hline
\end{tabular}

Tabel 8. Hasil uji signifikansi variabel beabs secara parsial

\begin{tabular}{|c|c|c|c|c|c|}
\hline Variabel & Rata-rata & Koe.regresi & $\mathbf{t}_{\text {hit }}$ & Sig. & Koef.determinasi parsial \\
\hline Konstanta & & $-55,691$ & $-2,740$ & 0,007 & \\
\hline$X_{1}$ & 104,69 & 0,418 & 2,778 & 0,006 & 0,051 \\
\hline$X_{2}$ & 91,34 & 0,464 & 3,323 & 0,001 & 0,070 \\
\hline$X_{3}$ & 94,19 & 0,321 & 2,727 & 0,007 & 0,053 \\
\hline
\end{tabular}

kan bahwa ada pengaruh yang signifikan antara disiplin belajar, lingkungan sosial, dan variasi gaya mengajar guru terhadap hasil belajar matematika siswa kelas XI IPA SMAN 3 dan SMAN 5 Samarinda tahun ajaran 2017/2018. Dari tabel 8 dapat diketahui bahwa nilai $b_{0}=-55,691$, $b_{1}=0,418, b_{2}=0,464$, dan $b_{3}=0,321$. $b_{0}$ adalah konstanta pada persamaan model regresi dugaan, dan $b_{1}, b_{2}, b_{3}$ masing-ma- matriks dapat meningkat jika siswa mempunyai disiplin belajar, lingkungan sosial, dan variasi gaya mengajar guru yang tinggi. Sebaliknya, jika disiplin belajar, lingkungan sosial, dan variasi gaya mengajar guru rendah maka hasil belajar matematika yang diperoleh siswa juga rendah. Berdasarkan hasil analisis data diperoleh nilai koefisien determinasi $R^{2}=0,136$, artinya pengaruh disiplin belajar, lingkungan sosial, dan 
variasi gaya mengajar guru secara bersamasama memberikan pengaruh terhadap hasil belajar matematika sebesar $13,6 \%$ dan $86,4 \%$ lainnya dipengaruhi oleh faktor lain yang tidak dijelaskan dalam penelitian ini. Dari ketiga variabel yang ada, dapat diketahui bahwa lingkungan sosial memberikan pengaruh yang paling besar terhadap hasil belajar matematika siswa kelas XI IPA SMAN 3 dan SMAN 5 Samarinda tahun ajaran 2017/2018 sebesar 7\%. Sedangkan untuk disiplin belajar dan variasi gaya mengajar guru memberikan kontribusi masing-masing sebesar $5,1 \%$ dan $5,7 \%$.

Hasil penelitian ini sejalan dengan hasil penelitian yang dilakukan oleh Saputra dan Pardiman (2012) di Universitas Negeri Yogyakarta bahwa ada pengaruh pengaruh positif disiplin belajar dengan prestasi belajar mahasiswa pendidikan akuntasi. Hasil penelitian Jeffrey dan Ade Zein (2017) menunjukkan terdapat pengaruh yang signifikan antara disiplin belajar terhadap hasil belajar siswa. Dengan demikian semakin baik disiplin belajar yang dimiliki siswa maka akan diikuti dengan meningkatnya hasil belajar siswa. Dari beberapa indikator yang dirumuskan untuk mengukur tingkat disiplin belajar siswa, ditemukan bahwa beberapa siswa tidak mengulang bahan pelajaran yang telah di pelajari sekolah, dan tidak menyiapkan diri untuk mempelajari bahan pelajaran sebelum kegiatan belajar dilakukan. Hal ini disebabkan karena siswa tidak berusaha menata dirinya untuk terbiasa hidup tertib, teratur, mentaati peraturan dan norma yang berlaku di sekolah maupun di rumah.

Lingkungan sosial memberikan kontribusi yang cukup tinggi dibandingkan dengan variabel yang lain dalam penelitian ini. Hal ini memperkuat pendapat Syah (2010) bahwa lingkungan sosial sekolah seperti para guru, staf administrasi, dan teman-teman sekelas dapat mempengaruhi semangat belajar siswa. Hasil penelitian ini sejalan dengan hasil penelitian Dhita Warantika (2016) di SMPN se-Kecamatan Samarinda Utara yang menunjukan bahwa terdapat pengaruh lingkungan sosial terhadap hasil belajar matematika. Dari beberapa indikator yang dirumuskan untuk mengukur lingkungan sosial siswa di sekolah ditemukan bahwa frekuensi interaksi antara siswa kurang lancar. Hal ini disebabkan karena siswa tidak saling membantu dalam setiap menyelesaikan persoalan di sekolah, dan beberapa siswa masih banyak yang mengisi waktu di dalam dan di luar sekolah untuk hal-hal yang tidak bermanfaat.

Pada variabel variasi gaya mengajar dilihat dari penggunaan variasi suara guru, pemusatan perhatian siswa, pemberian waktu, mengadakan kontak pandang dengan siswa, gerakan badan mimik, serta pergantian posisi guru di dalam kelas dapat disimpulkan termasuk dalam kategori sedang dengan presentase $35 \%$. Rata-rata skor variasi gaya mengajar guru sebesar 94,19 termasuk dalam kategori sedang. Dari beberapa indikator untuk mengukur variasi gaya mengajar guru ditemukan bahwa guru terlalu terlalu cepat dalam mengajar dan tidak memberikan waktu rileks ketika akan memasuki sub bab berikutnya, sehingga guru tidak mengetahui apakah siswa sudah memahami bab yang sedang di pelajari sebelum memasuki sub bab berikutnya. Hasil penelitian ini sejalan penelitian Jati (2016) bahwa terdapat pengaruh yang 
signifikan antara variasi gaya mengajar guru terhadap hasil belajar IPA. Hal ini diperkuat oleh Zainal Asri (2017), bahwa keterampilan mengadakan variasi (variation stimulus) dalam konteks proses pembelajaran yang ditunjukan guru untuk mengatasi kebosanan peserta didik, sehingga dalam proses situasi pembelajaran senantiasa menunjukkan ketekunan dan penuh partisipasi.

Dengan demikian, disiplin belajar, lingkungan sosial dan variasi gaya mengajar guru memberikan pengaruh positif terhadap hasil belajar matematika siswa baik secara bersama-sama maupun secara parsial.

\section{KESIMPULAN DAN SARAN}

\section{A. Kesimpulan}

1. Terdapat pengaruh disiplin belajar, lingkungan sosial di sekolah, dan variasi gaya mengajar guru terhadap hasil belajar matematika siswa kelas XI IPA SMAN 3 dan SMAN 5 Samarinda.

2. Terdapat pengaruh disiplin belajar siswa terhadap hasil belajar matematika siswa kelas XI IPA SMAN 3 dan SMAN 5 Samarinda.

3. Terdapat pengaruh lingkungan sosial terhadap hasil belajar matematika siswa kelas XI IPA SMAN 3 dan SMAN 5 Samarinda.

4. Terdapat pengaruh variasi gaya mengajar guru terhadap hasil belajar matematika siswa kelas XI IPA SMAN 3 dan SMAN 5 Samarinda.

\section{B. Saran}

Peranan disiplin belajar, lingkungan sosial di sekolah, dan variasi gaya mengajar guru terhadap hasil belajar matematika siswa SMA Kelas XI IPA secara signifikan. Oleh karena itu, pada diri siswa perlu dimotivasi pentingnya disiplin belajar matematika; perlunya ada perhatian lebih dari pimpinan lembaga sekolah terhadap lingkungan sosial; dan adanya variasi guru dalam mengajar matematika.

\section{DAFTAR PUSTAKA}

Asmani, J.M. (2013). 7 Tips Aplikasi PAKEM. Yogyakarta: Diva Press.

Azwar, S. (2012). Metode Penelitian. Yogyakarta: Pustaka Belajar

Farahdiba, T.S, Mahmud, H.R, dan Linda, V. (2017). Penerapan Keterampilan Mengadakan Variasi Stimulus Pada Proses Mengajar di Kelas 4 dan 5 SDN Lampageu Aceh Besar. Jurnal Ilmiah Pendidikan Guru Sekolah Dasar FKIP Unsyiah Vol. 2 No. 1.

Jati, T.K. (2016). Pengaruh Variasi Gaya Mengajar Guru dan Motivasi Belajar Siswa Terhadap Prestasi Belajar IPA (Survey Pada SD Segugus I di Kecamatan Kasihan Bantul). Jurnal Pendidikan Guru Sekolah dasar Edisi 16 Tahun ke-5 2016.

Jeffrey, I dan Zein. (2017). The Effects of Achievement Motivation, Learning Dicipline, dan Learning Facilities on Student Learning Outcomes. International Journal of Development Research, Vol. 07, Issue. 09.

Johari, Amin. (2006). Pengaruh Disiplin Belajar, Lingkungan Belajar, dan Variasi Gaya Mengajar Guru Terhadap hasil Belajar Ekonomi Pada Siswa Kelas X SMA Negeri PGRI 1 Kebumen Tahun Ajaran 2005/2006. Semarang: Universitas Negeri Semarang.

Mulyasa, E. (2008). Menjadi Guru Profesional Menciptakan pembela- 
jaran Kreatif dan menyenangkan. Bandung: Remaja Rosdakarya.

Slameto. (2013). Belajar dan Faktor-faktor yang Mempengaruhinya. Jakarta: Rineka Cipta.

Saputro, S. T dan Pardiman. (2012). Pengaruh Belajar dan Lingkungan Teman Sebaya Terhadap Prestasi Belajar Mahasiswa Program Studi Pendidikan Akuntansi Angkatan 2009 Fakultas Ekonomi Universitas Negeri Yogyakarta. Jurnal Pendidikan Akuntansi Indonesia, Vol. X, No. 1, Tahun 2012.

Slameto. (2013). Belajar Dan FaktorFaktor Yang Mempengaruhinya. Jakarta: Rineka Cipta.

Sugeng. (2014). Metode Penelitian Pendidikan Matematika. Samarinda: Purry Kencana Mandiri.

Sugiyono. (2010). Statistika Untuk Penelitian. Bandung: Alfabeta.

Sukardi. (2009). Metodologi Penelitian Pendidikan. Jakarta: Bumi Aksara.

Syah, M. (2010). Psikologi Belajar. Jakarta: Rajawali.

Thoha, I dan Wulandari. (2016). The Effect of Parents Attention and Learning Discipline on Economics Learning Outcomes. IOSR Journal of Research \& Method in Education, Vol 6, Issue 2, Ver. 1.

Walgito, B. (2008). Pengantar Psikologi
Umum. Yogyakarta: Andi Offset.

Wahyudi, E. T. (2010). Pengaruh Motivasi Belajar Siswa dan Variasi Gaya Mengajar Guru Terhadap Prestasi Belajar Akuntansi Siswa Kelas XI IPS SMA Virgo Fidelis Bawen Tahun 2009/2010. Skripsi Online. Semarang: FKIP UNNES.

Warantika, D. (2016). Pengaruh Lingkungan Sosial, Kondisi Ruang Kelas, dan Keaktifan Belajar Terhadap Hasil Belajar Matematika Siswa Kelas VII SMP se-Kecamatan Samarinda Utara Tahun Ajaran 2014/2015. Samarinda: Universitas Mulawarman.

Yopita, Sari. (2011). Hubungan antara Disiplin Belajar Terhadap Prestasi Belajar Matematika Kelas $V$ SD Negeri 4 Metro Utara Kota Metro. Skripsi. Bandar Lampung: Universitas Lampung.

Yuliyani, N.F. (2013). Hubungan Antara Lingkungan Sosial dengan Motivasi Belajar di Pesantren Madinatul Islamiyah. Spektrum PLS Vol.1, No.2.

Yuliatun. (2012). Pengaruh Lingkungan Sosial dan Motivasi Belajar Terhadap Prestasi Belajar Ekonomi Pada Siswa Kelas VII MTs Al Irsyad Ngawi Tahun Ajaran 2011/2012. Surakarta: Universitas Muhammadiyah Surakarta. 